\section{Congress goes for Nevada as site for nuclear waste storage}

Washington

Thirty years of debate and uncertainty have been brought to an abrupt end with a sudden congressional decision to name Yucca Mountain, Nevada, as the site of the United States' first repository for highlevel nuclear waste. The decision, one of the many last-minute deals made in Senate/House of Representatives conference committees as time ran out for agreement on the 1988 budget (see page 681), throws out the scientific site-selection process laid out in the 1982 Nuclear Waste Disposal Act. And although the legislation will still have be approved by both Senate and House, political expediency seems certain to win the day.

State officials in Nevada reacted with fury as they found the dump had been forced on them. Governor Richard $H$. Bryan attacked Congress's decision as a "legislative atrocity" that "blatantly rejects the laws of the land" and promised a "nuclear nightmare for Congress and the utility industry". The state will fight in the courts and "through whatever other avenues are needed".

The selection process abandoned in the new legislation had required the Department of Energy to prepare a short-list of six sites - three west of the Mississippi and three east - each stable enough to store radioactive waste for 10,000 years.

A site would then have been chosen in the west and, some years later, another in the east. But the process proved unworkable, despite the years of debate that went into its making. In May 1987, Energy Secretary John Herrington tried to take a short-cut by announcing three sites for investigation in the west - Hanford, Washington; Deaf Smith, Texas; and Yucca Mountain, Nevada - and giving up the search for sites in the east. But the resulting protest from westerners quickly led to demands to restart the whole process. At the same time it became clear, given the level of local opposition everywhere, that it might take decades to complete the assessment of even three sites. Meanwhile, nuclear waste would continue to pile up in temporary storage.

Earlier this year, J. Bennett Johnston, chairman of the Senate Energy Committee, attempted to find a way out by proposing that a $\$ 100$ million-a-year incentive be paid to any state willing to open the first high-level nuclear-waste dump. But the candidate states did not take the bait.

Now Nevada seems likely to be saddled with the dump. Local opponents remain convinced, however, that, in Governor Bryan's words, "scientific and technical concerns ignored on Capitol Hill will eventually disqualify Yucca Mountain".
The great advantage of Yucca Mountain, a 1,500-foot-high ridge of volcanic rock, is that it lies well above the water table. A shallow storage area, 1,200 feet below ground, would seem to permit easy access while avoiding the possibility that groundwater could leach radioactive wastes from storage containers. And Yucca Mountain is in one corner of the Nevada Nuclear Test Site and far from human habitation.

But state geologists argue that the site lies near an active fault and that a major earthquake might split it open. There is also evidence that a volcanic eruption might occur. More immediately, the local tourist industry might suffer when visitors find they have to share roads with trucks bearing nuclear waste.

All these fears will have to be addressed in the ensuing site investigation. And, if they turn out to be well founded, then the whole process will have to begin again at a

new site with a delay of many years. That risk, inevitable in investigating only one site, is one the Department of Energy says it is prepared to take because of the savings that will be made should Yucca Mountain be the right choice.

That site selection is no easy matter is clear from revelations last week concerning the United States' first permanent underground nuclear storage site, for lower-level wastes, near Carlsbad, New Mexico. Seven hundred million dollars have already been spent on a vast network of tunnels and storage rooms burrowed 2,000 feet into thick salt deposits. Back in 1957, the National Academy of Sciences recommended salt deposits as stable repositories because "no water can pass through salt". But, as University of New Mexico geologist Roger Y. Anderson put it, "the area was selected in haste and there have been plenty of geological surprises". The latest surprise is that the walls are weeping and there is a risk that drums of plutonium-contaminated waste from the manufacture of nuclear weapons may end up sitting in pools of corrosive brine.

Alun Anderson

\title{
Massachusetts adopts a model radwaste law . . . at long last
}

\section{Boston}

AFTER more than five years of negotiation and controversy, the state of Massachusetts recently enacted new regulations for the monitoring and storage of low-level radioactive waste. The bill, signed by the governor this month, has been hailed by industry and environmental observers alike as one of the most coherent and comprehensive in the country.

Due in part to the large number of hospitals, research laboratories and commercial companies specializing in biotechnology or the production of radiopharmaceutical products, Massachusetts ranks fifth among the states as a producer of low-level radioactive material, disposing of some 120,000 cubic feet of wastes and 110,000 curies annually. Until now, the state has handled these wastes under a series of essentially ad hoc regulations and has shipped them to one of three low-level waste disposal facilities in the United States: Hanford, Washington; Barnwell, South Carolina; or Beatty, Nevada.

Notably, the Massachusetts law mandates a new state agency intended to consolidate legal and technical expertise in radioactive waste management, which would monitor the long-term storage of these substances. In addition, although the bill does not specify the site or the technology of the state's ultimate disposal facility, it sets out a timetable and strict guidelines for its development.

Among these stipulations is an explicit rejection of the one method of disposal currently licensed by the Nuclear Regulatory Commission: shallow land burial. Instead, the bill says that if an in-state facility is ultimately required, it must adopt an "active management technology", one capable of continuously monitoring the stored wastes, and allowing the wastes to be repackaged should leaks or deterioration occur.

Also included in the bill are a new classification system that discriminates between the wastes by a weighted assessment of both toxicity and longevity, and strong state incentives for source reduction by the major waste producers.

In the wake of rising disposal costs and continued threats since the early 1980 s that future access to these disposal facilities would be denied, the pressure has been on many states to promulgate longterm management plans. Rhode Island has already adopted a version of the Massachusetts bill, and other states including New Jersey and Maryland are reported to be considering the plan.

Steven Roop, the state's assistant secretary for waste management policy, commended the legislative commission for "toiling over the entire range of issues involved. But he and others expressed frustration at the long process involved, especially since an almost identical form of the bill was endorsed unanimously by a legislative committee in early 1985.

Seth Shulman 